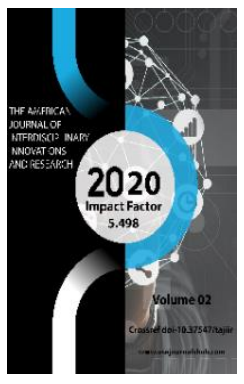

Copyright: Original content from this work may be used under the terms of the creative commons attributes 4.0 licence.

\section{Factors For The Development Of Aesthetic Education In Modern Pedagogy}

\author{
Bakhtiyor Akbarov \\ Senior Lecturer Of The Department Of Music Education, Namangan State University, \\ Uzbekistan \\ Mohicheha Abdulboqiyeva \\ Student Of The Faculty Of Music Education, Namangan State University, Uzbekistan
}

\title{
ABSTRACT
}

The music lesson is a leading scholar in the system of music education, because it covers sounds in a general way. Music lessons are different from other science lessons in that they are less artistically interesting and give children more creative pleasure, arousing emotional feelings and figurative experiences. Music, in particular, has a great positive effect on the mental and moral development of children.

\section{KEYWORDS}

Music, aesthetic education, music lesson, cognition, vocals.

\section{INTRODUCTION}

The teacher imparts knowledge to the students, guides the process of its reduction, checks and controls the actions of the students. These features provide a certain level of structure and consistency of the lesson. Before beginning the explanation, it is important to determine how well the students are prepared to master the new material and what knowledge they have. Teaching in the classroom is based on the general psychological characteristics of students from this group. The explanation is given to all 
students at the same time and what each student has the opportunity to be a teacher. As the child experiences the first relationship and knows what is around him, he begins to develop an aesthetic taste. The most intensive period of its formation is the school years, during which the child has the opportunity to regularly get acquainted with musical activities, his musical and creative abilities are actively developing. In educational work, the teacher draws the student's attention to the aesthetic qualities of life and art - music. It should be noted that a young person is more capable than an adult of direct emotional evaluation of everything he perceives. He simply decides whether he likes the choice or not. Gradually, the student develops a set of concepts that express personal recognition and goodwill. The fact that the child chooses the works that he likes more than others is an indication of his aesthetic taste. Aesthetic taste will be more specific and pedagogically controlled than other indicators of aesthetic maturity in the student. The teacher now has the opportunity to show the student that he or she will grow in the future based on his or her knowledge of artistic or, more broadly, musical-aesthetic preferences.

The student can answer the question of what kind of music they like the most. This music will be an indicator of the student's musical or aesthetic taste, and may even help him to understand his ideal, but there may not be concrete examples that represent the ideal. The instability of the concept of aesthetic ideal is characteristic of primary school children. The student may be interested in something as he learns. Adventure, interest in science fiction, passion for vocal and instrumental ensembles, passion for art television can be replaced by amateur art, and so on. At the same time, children develop the ability to evaluate the ideological and artistic content of the work, strengthen their interest in art and music. The task of music lessons is to teach children to be active in beauty, to have a creative approach to music. can be achieved. However, in the classroom, the understanding of music is the basis for all types of student activities. Understanding music is necessary for a full understanding of the life around you, because ultimately the ability to delve deeper into the essence of the work of art and the aesthetic thing in life contributes to the full development of the student's personality. Music lessons have the following tasks: to introduce students to the world of the great art of music, to teach them to love and understand music, along with its very rich forms and genres, in other words, to teach students music culture as part of their spiritual culture. The more active and purposeful a modern music lesson is, the higher the level of music education, not just music education. Music lessons are the basis of music education in primary school. The course consists of three interrelated sections: group singing, music literacy, and listening to music. These sections have recently been enriched by playing musical instruments, vocal improvisation, and movement to the sound of music.

One of the main tasks of music education for primary school students is to form an interest and love for music, to communicate with music, to enjoy music aesthetically, to understand its vital meaning. Children between the ages of seven and eight are not yet fully absorbed in music, nor are they able to reflect in their minds the musical image that is emerging today. At the same time, they can 
easily determine the general mood, notice the simplest means of musical expression, speed, enthusiasm, register. In order to organize an intensive and developmental complex of aesthetic education of the child in each school, it is necessary to eliminate the notion that the tasks and objectives of aesthetic education are one-sided. Understanding the beauties of the nature of our country, its surroundings, the beauties of relationships and science, the development of physical perfection has a much greater educational effect than just communication with literature and art. In order to develop children's understanding of music the basis of music education - it is necessary to allow them to experience in practice the variety of emotions, often expressed in choral or instrumental music. Singing as a group also has the potential to have an aesthetic impact on the performers and the audience. It facilitates media communication through music in cohesive movements. It helps to unite many souls into one strong feeling soul. That is his great educational potential. It doesn't matter what kind of song they sing to bring up their children properly. It is important to use songs on topical issues, as such songs inform children about all the thoughts and feelings of our people, bring school life closer to today's events. All the students of the school sing songs about the holidays of our people, about childhood and youth. The beauty of Mother Nature and the hard work of the people associated with it also delight students. The whole class sings as a group. It is true that children who sing incorrectly at first interfere with the general song, the purity of the tones: but it should be remembered that children's ability to listen to music and voice, although not well developed, gradually develops in the process of learning. Vocal development is a long process. That's why we cannot deprive students of the opportunity to develop both by listening to music and by not having a good voice. The skills and competencies a student acquires are directly related to the age characteristics of his or her growth and cognition. The national education system plays an important role in improving the quality and effectiveness of lessons in educational institutions. Of course, this is an important psychological experience; first of all, it is caused by the decision of each person, the layers of this nation.

While teaching music lessons at educational institutions, it is highly beneficial that the classes are based on our national heritage. In the course of the lesson, especially by teaching songs that glorify Uzbek customs, the ideas of national mentality are formed in the minds of young people, reflecting on their traditions, dressing, and Uzbek cuisine. It is necessary to use national values wisely and develop the ability to feel the national tones, especially, in the process of spiritual upbringing of young people. If we want to glorify Uzbekistan, its ancient history and bright future, to keep it in the memory of generations, we must first of all bring up our great composers, great writers, great poets, great creators. As the great writer Chulpan said, the idea that a nation lives if literature lives is a clear example of this. Therefore, the art of music plays an important role in educating the younger generation. It is no exaggeration to say that the art of music is one of the rarest monuments of the national identity of our ancestors.

It should be noted that the Uzbek folk, classical songs and hymns are based on folklore or texts related to classical poetry. Poetic works 
created by representatives of classical literature are highly valued by our people as examples of high creativity.

In the course of research on the pedagogical basis of the organization of music and aesthetic education and upbringing through classical music, we are convinced that there are serious and unresolved issues in the organization and teaching of classical music in secondary schools. These include, but are not limited to:

1. Inadequate training of teachers in Uzbek classical and makam music in secondary schools;

2. Lack of special methodology to ensure the quality and effectiveness of the process of theoretical and practical study of classical music;

3. Lack of special sound library, visual and technical aids due to the priority given to singing and listening to classical works in school education;

4. Lack of popularization of experiments on pedagogical, methodical, didactic organization of lessons on classical music and creation of special methodical manuals.

Solving these problems creates an opportunity for the works of acquainting students with the art of Uzbek classical singing in secondary schools, and instilling in them a respect, love for national folk music, a desire to study them, and thus educating them in the spirit of national ideas and ideology to be effective.

\section{REFERENCES}

1. Islam Karimov. "Towards a great future",Tashkent: "O'zbekiston", 1998
2. Abdurauf Fitrat "Uzbek classic music and its history", Tashkent: 1993

3. Golom Zafariy "The delicacy of Uzbek music", 1992

4. T.Ortikov "Methodology of teaching music", Tashkent: "Muharrir" 2000

5. http://journalnx.com/journalarticle/20150932 